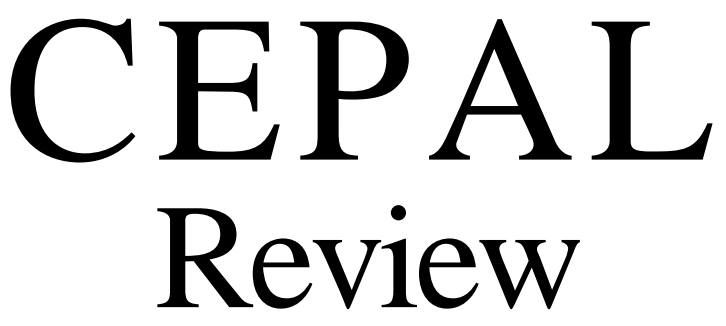

Executive Secretary

Norberto González

Deputy Executive Secretary for

Economic and Social Development

Gert Rosenthal

Deputy Executive Secretary for

Co-operation and Support Services

Robert T. Brown

Technical Secretary

Adolfo Gurrieri

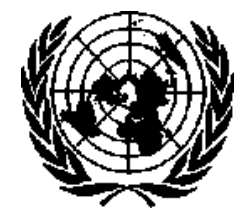

UNITED NATIONS

ECONOMIC COMMISSION FOR LATIN AMERICA AND THE CARIBBEAN

SANTIAGO, CHILE, DECEMBER 1986 


\section{CEP AL}

Review

Santiago, Chile

Number 30

\section{CONTENTS}

Reactivation and development: the great commitment of Latin America and the Caribbean.

Norberto González,

Alleviation of the debt burden: historical experience and present need. Carlos Massad.

From austerity measures to structural adjustment. Lucio Geller and Víctor Tokman.

External debt and the reform of the international monetary system. Arturo O'Connell.

The origin and magnitude of the recessionary adjustment in Latin America.

Richard L Ground.

Turning page in relations between Latin America and the Caribbean countries. Elvio Baldinelli.

The international division of industrial labour and the core-periphery concept.

Kimmo Kiljunen.

Services: a disquieting link between Latin America and the world economy. Francisco Javier Prieto.

Technology transfer in the mining sector: options for the Latin American Mining Organization (OLAMI). Michael Nelson.

The role of the public sector and transnational corporations in the mining development of

Mining development in relation to the origin of capital. Patricio Jones.

New objectives for the development of mining resources. Rolando Sanz Guerrero.

Recent BCLAC publications. 


\section{Origin and magnitude of recessionary adjustment in Latin America}

\section{Richard L. Ground*}

Notwithstanding the enormous efforts made by the Latin American countries in the last five years to adjust their economies and despite the fact that the citizens of the developed nations are enjoying the benefits of the longest expansionary phase in the postwar period, the great majority of the peoples òf the region find themselves immersed in one of the most profound economic crises in their history. They are enduring simultaneously a severe external constraint; levels of production and employment substantially and increasingly below their trend values; and, in many cases, inflations of exceptional virulence, although since mid-1985, several countries have achieved spectacular advances towards price stabilization.

In effect, the adjustment undergone by the Latin American countries has been unnecessarily costly and their recovery unduly and painfully slow. The markedly recessionary character of the adjustment suffered by the peoples of the region is chiefly the result of the acute scarcity of foreign finance. Hence the achievement of efficient adjustment and a timely and vigorous recovery largely depends on reforms of the lending policies of the international financial community that translate into a supply of credit in keeping with the impact of external shocks on deficit countries' balance of payments as well as with their capacity to absorb real falls in domestic expenditure without losses in production. On the other hand, the achievement of a more solid and autonomous development process means that Latin America must reduce its structural dependence on external financing, which depends, in turn, on the adoption of domestic policy reforms.

-Staff member of the Economic Development Division of the Economic Commission for Latin America and the Caribbean (ECLAC). A partial and preliminary version of this study, which was originally written in Spanish, was presented to the Seminar on Economic Crisis and Development Prospects in Latin America, organized by the National Development Council (CONADE), the Latin American Faculty of Social Sciences (FLACSO) and the Latin American Institute forSocial Research (ILDIS) (Quito, 28 to 31 July 1986). The author is grateful for the very valuable comments made by Adolfo Gurrieri on the preliminary version of this paper. He also thanks Raúl Pina for his efficient processing of text and statistical tables. The author alone is responsible for any errors or shortcomings.

\section{Adjustment and efficiency}

The logic of the adjustment process is implacable, for it is rooted in a budgetary constraint: the impossibility of absorbing more goods and services than those available, including, of course, both those produced domestically and those acquired from abroad by means of factor income, foreign loans and domestic holdings of international reserves. The process is automatic as well as inevitable according as the gap between gross domestic expenditure and gross national income becomes untenable, i.e., when international reserves are exhausted and foreign lending, voluntary or otherwise, ceases. ${ }^{1}$ It entails the narrowing of the gap between gross domestic investment and gross national saving —or, what amounts to the same thing, the reduction of the deficit on the balance-of-payments current account- to an amount compatible with the availability of external finance. These being the inescapable facts of adjustment, the pertinent question is how to minimize their cost.

The logic of the process is unconnected with the sources of disequilibria, whether the causes be domestic or external, transitory or permanent. Neither can it be counteracted by domestic economic policy. Nonetheless, the questions associated with the origin and duration of shocks are pertinent to the design of international adjustment policies, that is, they help to determine the optimum mix of foreign financing and domestic adjustment. ${ }^{2}$ Indeed, a deficit attributable to transitory external shocks should be financed for the sake of efficiency because the cost of eliminating a deficit ascribable to a temporary change in external conditions is generally much greater than the cost of sustaining it.

\footnotetext{
${ }^{1}$ A condition implicit throughout this analysis.

${ }^{2}$ By the term "shock" we mean phenomena such as the rise in the actual international interest rate, the fall in the actual average price of exports and retrenchment in the actual flow of credit from the international commercial banks in relation to their respective trend values.
} 
The adjustment process imposes an inevitable cost, even in an economy free of imperfections; namely, the loss of welfare caused by the fall in absorption of goods and services involved in the elimination of a current account deficit, whatever the origin of the imbalance. In contrast, the cost of financing a deficit does depend on what type of shock has caused it. Thus, whereas the cost of postponing an inevitable adjustment - that is, of sustaining indefinitely a deficit provoked by domestic economic policies or permanent mutations in international market conditions - is always greater than the inevitable cost of adjustment, the cost of financing a deficit stemming from transitory external shocks is less than the inescapable welfare loss inherent in the elimination of the deficit. Consequently, adjustment to deficits caused by transitory external shocks, whether voluntary or forced by a lack of foreign finance, is inefficient and represents an overadjustment.

Now, in economies free of imperfections - that is, in those that belong to the realm of the abstract- adjustment would not cause any production loss; in contrast, in real world economies, affected as they are by imperfections of varied type and intensity, a brusque and complete adjustment to the impact of any type of shock inevitably depresses the actual growth rate of economic activity vis-à-vis its potential rate when it does not reduce the actual level of gross domestic product. ${ }^{3}$ Therefore, although a current account deficit may be due to domestic

'Two classes of imperfections may be identified. One comprises those inherent to the existence of time and uncertainty. The rigidities and lags they engender prevent instantaneous reallocations of productive resources in the directions and magnitudes required to maintain them fully utilized, even if the economy be free of structural and institutional defects and if domestic economic policies be those full employment requires. The other class embraces the structural and institutional imperfections policy shocks or permanent external ones, the minimization of welfare losses demands in addition a speed of adjustment consistent with the capacity of the imperfect economies of the real world to cope with falls in absorption without incurring losses in output. ${ }^{4}$ This requisite implies that the impact of permanent external and domestic policy shocks also should be partially and temporarily financed. Indeed, in the absence of an optimum mix of financing and adjustment of the balance-of-payments effects of shocks over time, not only will countries be forced to endure an overadjustment (when foreign finance does not cover the impact of transitory external shocks), but will also have to suffer needless welfare losses (when foreign finance is insufficient to enable the countries to adjust without suffering production losses). Once again, without financing adjustment is inevitable, but adjustment in itself does not require production losses. Indeed, any output foregone during the process of adjustment is unnecessary and unjustified.

Nonetheless, whether the international financial community will be willing to provide the essential resources to forestall a needlessly costly adjustment is quite another matter, even though in the past it often financed deficits which, on efficiency grounds, should have been eliminated. In practice, the criterion that has determined the magnitude, velocity and cost of the adjustment process that deficit Latin American countries have had to endure has not arisen from efficiency considerations.

that arise over time as a result of flaws in domestic economic policies. This type of imperfection also blocks the full employment of resources.

${ }^{4}$ It also indicates that the cost of adjustment to transitory external shocks is in fact greater than the welfare loss caused by the elimination of the deficit. 


\section{II}

\section{Resource transfers and unnecessary welfare losses}

In the last five years the Latin American peoples have suffered and continue to suffer a dramatic adjustment. Thus, in the $1982 / 1985$ period they have generated enormous surpluses on their trade accounts, transferring to the creditor countries US\$ 105 billion (see table 1).

It is evident that this adjustment has been very onerous, since each dollar transferred abroad is a dollar of goods and services that the countries of the region have not consumed or invested. But the really tragic aspect is that it has been, and still is, unnecessarily costly, from the standpoint of both the logic of adjustment itself and the development potential of the Latin American countries. What is more, although this process has been considered quite an achievement in the North (and why not? - since from their point of view the results might not only have been much less satisfactory, but their own economies are prospering independently of the fate of the developing countries), the Latin American peoples have found themselves obliged to pay their bills many times over.

Table 1

\section{LATIN AMERICA: GLOBAL SUMMARY OF BALANCE OF} PAYMENTS AND EXTERNAL DEBT

(Millions of dollars)

\begin{tabular}{|c|c|c|c|c|c|c|c|c|}
\hline & 1978 & 1979 & 1980 & 1981 & 1982 & 1983 & 1984 & 1985 \\
\hline Trade balance & -8480 & -6211 & -10121 & -12613 & -1354 & 27003 & 33969 & $\begin{array}{r}30935 \\
-31658 "\end{array}$ \\
\hline $\begin{array}{l}\text { factor service } \\
\text { payments }\end{array}$ & -6738 & -9630 & -13916 & -22135 & -33627 & $-30967-$ & -32901 & \\
\hline $\begin{array}{l}\text { alance on current } \\
\text { account }\end{array}$ & -9912 & -13462 & -18031 & -27552 & -39597 & -34630 & -35876 & -3203 \\
\hline $\begin{array}{l}\text { Balance on capital } \\
\text { account }\end{array}$ & -18392 & -19673 & -28152 & -40165 & -40951 & $-7 \quad 627$ & -1907 & 6043 \\
\hline Long-term capital ${ }^{c}$ & 26208 & 29092 & 29546 & 37287 & 19881 & 3220 & 10206 & $6000^{\circ}$ \\
\hline Short-term capital & 25837 & 22844 & 28275 & 46465 & 34545 & 19230 & $12000^{\circ}$ & $43 "$ \\
\hline $\begin{array}{l}\text { Variation in interna- } \\
\text { tional reserves }\end{array}$ & $\begin{array}{r}374 \\
7757\end{array}$ & $\begin{array}{ll}6 & 251 \\
9 & 787\end{array}$ & $\begin{array}{ll}1 & 271 \\
2 & 231\end{array}$ & $\begin{array}{l}-9178 \\
-1843\end{array}$ & $\begin{array}{rr}-14 & 664 \\
-19 & 191\end{array}$ & $\begin{array}{rr}-16 & 010 \\
-3 & 755\end{array}$ & $\begin{array}{rl}-1 & 794 " \\
8 & 298\end{array}$ & 840 \\
\hline Resource transfers & 15925 & 15630 & 11515 & 8735 & -19716 & -31410 & -25670 & -28095 \\
\hline $\begin{array}{l}\text { ross disbursed } \\
\text { external debt }\end{array}$ & & 189950 & 230235 & 287709 & 330702 & 350123 & 366493 & 820 \\
\hline et external debt & 20169 & 141178 & 176458 & 241577 & 298367 & 319624 & 329558 & 339860 \\
\hline
\end{tabular}

Source: ECLAC's data bank.

"Estimates.

Includes private unrequited transfers.

includes official unrequited transfers.

Includes errors and omissions. 
Table 2

LATIN AMERICA: SUMMARY MACROECONOMIC INDICATORS, 1981-1985

\begin{tabular}{|c|c|c|c|c|c|c|c|c|c|c|c|c|c|c|c|c|c|c|c|c|c|c|c|c|c|}
\hline \multirow[t]{2}{*}{ Country } & \multicolumn{5}{|c|}{$\begin{array}{l}\text { Per capita gross } \\
\text { domestic products }^{0}\end{array}$} & \multicolumn{5}{|c|}{ Output gap* } & \multicolumn{5}{|c|}{$\begin{array}{l}\text { Gross domestic } \\
\text { absorption }{ }^{a c}\end{array}$} & \multicolumn{5}{|c|}{ Foreign currency gap $^{d}$} & \multicolumn{5}{|c|}{ Inflation' } \\
\hline & 1981 & 1982 & 1983 & 1984 & 1985 & 1981 & 1982 & 1983 & 1984 & 1985 & 1981 & 1982 & 1983 & 1984 & 1985 & 1981 & 1982 & 1983 & 1984 & 1985 & 1981 & 1982 & 1983 & 1984 & i98y \\
\hline Argentina & -8.2 & -7.8 & 14 & 0.5 & -5.5 & 15.2 & 21.4 & 22.8 & $23-9$ & 28.7 & -8.4 & -10.8 & 1.7 & 2.7 & -5.8 & $g$ & 14.2 & 34.0 & 31.3 & 54.8 & 131.2 & 208.7 & 433.7 & 688.0 & 385.4 \\
\hline Bolivia & -2.9 & -0.9 & -9.7 & -5.6 & -4.7 & -2.4 & 8.0 & 19.1 & 25.1 & $29-7$ & 1.2 & -11.1 & -6.6 & -3.5 & -16.4 & 31.7 & 82.2 & 71.8 & 70.5 & 66.4 & 25.2 & 296.5 & 328.5 & 2177.2 & $\begin{array}{ll}8 & 170.5\end{array}$ \\
\hline Brazil & -4.2 & -0.9 & -4.9 & 2.5 & 5.8 & 12.1 & 17.5 & 25.6 & 27.7 & 28.0 & -Í.0 & 1.3 & -5.6 & 2.4 & 9-0 & 41.0 & 438 & 74.0 & 20.4 & 100.6 & 91.2 & 97.9 & 179.2 & 203.3 & 223.0 \\
\hline Colombi & 0.1 & -1.1 & -1.0 & 1.4 & 0.5 & -0.2 & 3.8 & 7.6 & $9 A$ & 12.1 & 3.5 & 2.3 & 1.0 & 1.3 & 10.9 & -76.0 & -83.3 & -16.3 & 20.4 & 41.6 & 27.5 & 24.1 & 16.5 & 18.3 & 22.5 \\
\hline Costa $\mathrm{F}$ & -5.0 & -9.7 & - & 4.6 & -1.0 & 16.8 & 27.8 & 30.8 & 31.3 & 35.6 & -11.5 & -10.2 & 28.2 & -12.8 & 0.4 & 67.3 & 79.8 & 79.0 & 78.2 & 78.8 & 65.1 & 81.7 & 10.7 & 17.3 & 10.9 \\
\hline Ecuado & 0 & -1.8 & -4.4 & 1.7 & -0.2 & -11.6 & -7.6 & 2.3 & 5.1 & 8.2 & 3.1 & 0.1 & $-9-2$ & 3.4 & 11.1 & 132.8 & -8.6 & 89.8 & 87.5 & 897 & 17.9 & 24.3 & 52. & 25.1 & 24.4 \\
\hline EI Salvador & 11.0 & -8.4 & -3.8 & -1.5 & -1.6 & 29.3 & 36.6 & 40.2 & 42.4 & 44.5 & -5.1 & -6.2 & -3.3 & 4.1 & -11.0 & 64.2 & 75.0 & 78.5 & 76.9 & 76.9 & 11.6 & 13.8 & 15.5 & 9.8 & 32.1 \\
\hline Guatemala & -1.8 & -6.1 & -5.5 & -2.6 & $-3-7$ & -1.7 & 9.9 & 16.7 & 20.7 & 25.8 & -31.2 & -6.8 & -4.6 & 0.3 & -8.1 & 7.5 & 63.9 & 84.8 & 81.7 & 88.6 & 8.7 & -2.0 & 15.4 & 5.2 & 31.5 \\
\hline Guyanz & -2.6 & -12.6 & -12.0 & 3.9 & & & & & & & & & & & & & & & & & 29.1 & 20.3 & 13.3 & 27.4 & \\
\hline Hai & & -6.4 & -2.3 & 0.2 & -1.4 & -1.8 & 9.1 & 12.5 & 13.7 & 15.9 & -0.2 & -7.8 & 0.1 & 3.0 & -3.0 & -21.3 & 23.7 & 36.7 & 44.5 & 58.9 & 16.4 & 6.2 & 12.2 & 6.1 & 15.0 \\
\hline Hond & -2.8 & -4.0 & -4.5 & -0.8 & -1.7 & -3.7 & 2.3 & 6.8 & 8.1 & & -2.3 & -5.2 & -1.0 & 3.0 & 3.0 & 27.0 & 64.0 & 61.7 & 60.2 & 56.3 & 9.2 & 8.8 & 7. & 3.7 & 4.2 \\
\hline Jamaica & 1.1 & -1.6 & - & -1.7 & & & & & & & & & & & & & & & & & 4.8 & 7.0 & 16.7 & 31.2 & 22.8 \\
\hline Mexico & 5.4 & -2.6 & -7.6 & 0.9 & - & -3.2 & 3.8 & 14.5 & 17.0 & $19-4$ & 91 & -5.3 & -9.1 & 4.4 & 12.1 & $g$ & 146.0 & $g$ & g & -400.0 & 28.7 & 98.8 & 80.8 & $59-2$ & 63.7 \\
\hline Nicaragua & 2.0 & -4.4 & 1.3 & -4.8 & $-5-9$ & 36.9 & 41.0 & 41.6 & $43-9$ & 49.8 & 3.6 & -4.8 & $3-8$ & 0.8 & 2.4 & 39.4 & 59.8 & 60.0 & 63.7 & 65.5 & 23.2 & 22.2 & 32.9 & 50.2 & 334.5 \\
\hline Panama & 1.7 & 2.7 & -2.2 & -2.5 & 1.1 & 4.8 & 5.7 & 11.1 & 17.6 & 21.4 & 5.2 & -43 & 4.9 & 0.7 & 11.1 & 63.7 & 68.1 & 82.6 & 86.2 & 87.9 & 4.8 & 3.7 & 2.0 & 0.9 & 0.8 \\
\hline Peru & 1.0 & -2.7 & -14.3 & 1.8 & -0.6 & 13.9 & 17.5 & 29.8 & $29-8$ & 31.6 & 6.7 & $-1-3$ & -12.6 & 2.0 & -3.8 & 15.6 & 38.2 & 69.4 & 90.0 & 94.9 & 72.7 & 72.9 & 125.1 & 111.5 & 158.3 \\
\hline \multicolumn{26}{|l|}{ Dominican } \\
\hline & 1.5 & -1.1 & 2.2 & -1.6 & -4.4 & -1.0 & 2.1 & 3.8 & 8.5 & 14.4 & 0.4 & -0.6 & 4.2 & -1.1 & 8.0 & 46.5 & 47.5 & 68.6 & 84.2 & 88.8 & 7.4 & 7.1 & 9.8 & 40.9 & 39.4 \\
\hline \multicolumn{25}{|l|}{ Trinic } & 6.9 \\
\hline Uruguay $^{1}$ & 0.3 & -11.3 & & & & & 8.8 & 16.2 & 20.5 & & -1.2 & -10.0 & -9.6 & -3.2 & -16.8 & 185.8 & 51.3 & 92.4 & 89.4 & 85.5 & 29.4 & 20.5 & 51.5 & 66.1 & 83.0 \\
\hline Venezuela & $-3-9$ & -4.1 & -8.2 & -3.7 & $-3-8$ & 21.0 & 25.0 & 33.2 & 38.1 & 58.4 & 0.6 & 5.7 & -19.5 & -0.1 & -10.3 & $g$ & $g$ & $g$ & $g$ & - & 10.8 & 7.9 & 7.0 & 13.3 & $5-8$ \\
\hline
\end{tabular}

Source! On rhe basis of ECLAC data bank and ECLAC (1985) tables 3 and 5 .

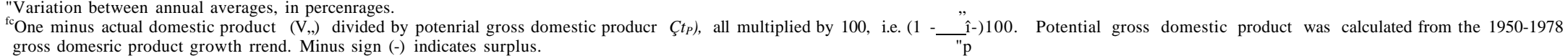

'Of goods and non-factor services.
'One minus the aaual currenr account deficit $\left(\mathrm{D}_{\mathrm{a}}\right)$ divided by the potential current account deficit (Dp\}, all multiplied by 100, Le. $\left(1 \frac{\mathrm{rj}}{D p}\right) 100$. The potenrial current accounr deficit is defined

as the current account deficit that would be observed if the quantum of imports of goods and non-faaor services equalled its trend value, given rhe aaual values of the other balance-of-payments variables. The 1981-1985 rrend values were calculated on the basis of the trend growth rate recorded in the 1950-1978 period The minus sign (-) indicates surplus.

'Percentage change from December to December.

For the twelve monrhs rerminaring in the last month for which there are data available

*The potential current accounr deficit is positive.

"The 1981-1985 trend values were calculated on the basis of the trend growth rate observed in rhe period 1968-1978.

'Up to 1981 the trend values were calculated on the basis of the trend growth rate recorded in the period 1972-1978; from 1982 to 1985 the trend growth rare estimated from dara for the period 1950-1978 was applied ${ }^{\mathrm{J}}$ The 1981-1985 rrend values were calculated for the period 1972-1978. 
Indeed, whereas in 1981, after 30 years of uninterrupted economic development, over half the Latin American countries recorded production and employment levels above their respective trend values, in 1983 there were production gaps in all the countries of the region. They amounted to $18 \%$ in that year, to then expand to $21 \%$ and $25 \%$ in the two following years (see table 2 ). ${ }^{5}$

The welfare losses resulting from these output gaps were in the order of US\$ 690 to 810 billion in the four-year period 1982-1985. The former figure is almost equal to, and the second is greater than, the actual value of the total gross domestic product of the region in $1985 .{ }^{6}$ For each dollar transferred abroad during that period around 7 or 8 dollars worth of production were

*By definition, the output gap is equal to the difference between actual and potential levels of economic activity. In accordance with the conventional method, potential values of gross domestic product have been estimated on the basis of trend values. In practice, therefore, the output gap equals the shortfall between the actual level of economic activity and that which would have been achieved if the trend rate ofgrowthhadobtained.lt measures production unrealized or foregone and gives an indication of the overall efficiency of the economy. For greater details on the calculations given here see note ${ }^{7}$ below and note $\mathrm{b}$ of table 2 .

${ }^{6}$ The lower figure was estimated by comparing actual and potential gross domestic product, both calculated on the basis of ECLAC figures on the amount of the regional gross domestic product in dollars at 1970 prices at the parity exchange rate. The difference between actual and potential product were converted to dollars of each year using conversion factors calculated according to the evolution of the United States wholesale price index. For values of the potential gross domestic product those of trend gross domestic product were used; these, in turn, were estimated on the basis of ECLAC data for the 1950-1978 period. (The estimate, carried out by the conventional method, recorded a trend growth rate of $5.63 \%$.) The higher estimate of production losses was obtained by using the World Bank's annual calculations of actual gross national products in dollars and the data on the balance of payments supplied by the IMF and ECLAC, as well as a transformation of the estimate of the trend values of the gross domestic product. To the World Bank data were added the net lost. We thus find ourselves faced with a phenomenal wastage of resources; again, production losses are not inherent in the adjustment process.

An adjustment so needlessly costly as the one suffered by Latin America may issue, rather, from an unwarranted dearth of foreign finance, i.e., from international capital market imperfections and procyciical lending policies by the international financial community; from deficient adjustment policies, i.e., from inadequate international conditionality as well as unsuitable economic policies in the countries themselves, or from both an untoward shortage of external finance and deficient adjustment policies. factor service payments of the corresponding balances of payments to obtain the actual values of the regional gross domestic product. (However, in the absence of World Bank statistics for 1985, a figure had to be obtained by multiplying its data for 1984 by the growth rate calculated by ECLAC for 1985.) To generate comparable values for the potential gross domestic product, the figures estimated with ECLAC data were converted by means of a factor of conversion to the value of the actual gross domestic product estimated on the basis of the World Bank data for that year. This conversion factor was calculated in accordance with the ratio observed between actual output (ECLAC data) and the trend values for 1982. To obtain those of the following years the trend growth rate estimated with BCLAC statistics was applied. The difference between the two estimates is mainly due to the fact that the World Bank calculations reflect the rises in the real exchange rates of the Latin American economies and therefore show an appreciable fall in the value of their gross domestic product measured in dollars, while those of ECI.AC do not take these rises into account and record, therefore, a less unfavourable evolution of the regional gross domestic product. (The ECLAC figures for the gross domestic product in the period 1950-1985 were obtained from their data bank, The data for the net factor service payments were taken from ECLAC (1985a, 23,30 and 31) and (1985b, 44 and 46).) For the World Bank data see World Bank $(1985,174-175)$ and (1984, 240-241). 


\section{Causes of inefficient adjustment in Latin America}

\section{External causes}

\section{a) Scarcity of foreign finance}

The international financial community has shown itself reluctant to finance exceptionally large current account deficits for more than a few years, and even less disposition to do so for indefinite periods, even though such deficits may be attributable to transitory external shocks. Experience shows that several years of large deficits generally sees a retrenchment by the international financial community, apart from any consideration of efficiency from the standpoint of any one country or the system as a whole. Furthermore, although it may be highly detrimental to the international economy and the countries directly affected, such a retrenchment usually originates in rational decisions adopted by each individual bank. ${ }^{7}$ International capital market imperfections are indeed responsible for a large part of the unnecessary welfare losses experienced by the Latin American countries in recent years.

If the international economy raises adjustment costs unnecessarily or shows itself incapable of coping efficiently with shocks, it is the duty of governments to implement compensatory measures. It was precisely considerations of this kind that led the governments to create the International Monetary Fund. Nevertheless, over time the lending capacity of the IMF was allowed to lag far

'As Sachs (1984) observes, "Recent theorizing has shown how such "herd behaviour" (the widespread paralyzation of new loans that occurred in 1982) can result from the rational decisions of individual banks. ...The main point of this theorizing is that each bank's loan decision is properly affected by the loan decisions of other banks. Since no bank alone can extend all of the credit that Mexico or Brazil needs to stay afloat, it is prudent for each bank to lend new money only if other banks are making new loans as well. Because of this interdependence of the banks' decisions, aggregate bank lending may stop not because the country's position has changed, but because each individual bank believes chat all of the other banks have decided to stop lending. The prophecy of a loan cutoff can then become self-fulfilling". (The parentheses were added by the author; the content is from the article cited.) behind world trade and international capital flows.

Thus, while the ratio between the total value of IMF quotas and the value of world trade in the period 1950-1969 fluctuated between 9\% and $11 \%$, in the 1980 s it was allowed to fall to an average of around $4 \%$ (IMF, several years). The value of the quotas of the countries in the IMF, which largely determines the amount of financing to which they have access, likewise fell markedly in relation to the value of their foreign trade and capital movements. It is not surprising, then, that in recent years, characterized by enormous shocks, there has been an irrational rationing of foreign credit. In fact, confronted by an acute shortage of funds in relation to developing country demand for credit, the IMF was forced to condition the use of its funds to the realization of huge adjustments by deficit countries. Although it is true that these adjustments would have occurred in any case in view of the retrenchment of the commercial banks, the Fund also promoted far-reaching adjustments in developing countries in the 1980s, apparently convinced that the drastic fall in their terms of trade was likely to be permanent (de Larosière, 1982).

After 1981, as a result of the restriction of commercial bank credit and the lack of a compensatory policy on the part of the international financial community, the actual capital flow to the non-oil-exporting Latin American countries eventually even fell below its trend value, in circumstances in which the impact of shocks continued to increase appreciably $^{8}$ (Ground 1986, table 7). As a result,

\footnotetext{
${ }^{8}$ Actual long-term net foreign financing (including private unrequited transfers) ranged from US| 25837 million in 1978 to 22844 in 1979, 28275 in 1980, 46475 in 1981, 34545 in 1982, 19230 in 1983, 12000 in 1984 and 6000 in 1985. In its turn, the overall surplus on the capital account (including the net movement of short-term capital and errors and omissions) fluctuated from USÎ 26208 million in 1978 to 29092 in 1979, 29546 in 1980, 37287 in 1981, 19881 in 1982, 3220 in 1983,10 206 in 1984 and 6043 in 1985 (see table 1).
} 
Table 3

LATIN AMERICA: ESTIMATE OF THE DEFICIT (FINANCING) OWED AND THE ACTUAL FOREIGN FINANCING OF THE NON-OIL-EXPORTING COUNTRIES"

\begin{tabular}{|c|c|c|c|c|c|c|c|c|c|c|c|c|c|c|c|}
\hline \multirow{3}{*}{ Country } & \multirow{2}{*}{\multicolumn{5}{|c|}{$\begin{array}{l}\text { Estimate of warranted current } \\
\text { account deficit }\end{array}$}} & \multicolumn{10}{|c|}{ Actual net foreign financing ${ }^{c}$} \\
\hline & & & & & & \multicolumn{5}{|c|}{ Total } & \multicolumn{5}{|c|}{ From the IMF } \\
\hline & 1981 & 1982 & 1983 & 1984 & $1985^{\mathrm{d}}$ & 1981 & 1982 & 1983 & 1984 & $1985^{\text {rf }}$ & 1981 & 1982 & 1983 & 1984 & $1985^{\mathrm{e}}$ \\
\hline Argentina & 3522 & -4242 & -7424 & -3371 & -5318 & 1261 & 1592 & 1102 & 2561 & 2700 & - & - & 1238 & - & 993 \\
\hline Brazil & -23076 & -36242 & -33396 & -24236 & -32180 & 12357 & 12798 & 7411 & 7268 & 1500 & - & 551 & 2167 & 1788 & $\cdot 66$ \\
\hline Colombia & -1286 & -2687 & -2932 & -2794 & -2368 & 2104 & 2125 & 981 & 593 & 885 & - & - & - & - & - \\
\hline Costa Rica & -1533 & -1340 & -919 & -1469 & -1389 & 347 & 384 & 418 & 465 & 460 & 51 & -4 & 106 & 25 & 19 \\
\hline Chile & -5099 & -5442 & A 807 & -5706 & -6269 & 4592 & 970 & 1248 & 2376 & 1230 & -68 & -40 & 613 & 221 & 198 \\
\hline El Salvador & -556 & -632 & -611 & -772 & -973 & 266 & 308 & 306 & 315 & 410 & 39 & 65 & 18 & -5 & -26 \\
\hline Guatemala & -407 & -431 & -780 & -949 & -973 & 279 & 362 & 323 & 378 & 160 & 113 & - & 41 & 20 & -36 \\
\hline Haiti & -324 & -263 & -487 & -511 & -392 & 231 & no & 182 & 195 & 170 & 18 & 12 & 31 & 14 & -10 \\
\hline Honduras & -470 & -609 & -688 & -697 & -821 & 272 & 261 & 261 & 325 & 360 & 24 & 68 & 50 & 2 & -15 \\
\hline Nicaragua & -622 & -1001 & -704 & -708 & -912 & 610 & 574 & 536 & 539 & 580 & -21 & -3 & -5 & -4 & -9 \\
\hline Panama & -788 & -250 & -1411 & -1734 & -2016 & 495 & 519 & 441 & 330 & 356 & 73 & -4 & 116 & 95 & 6 \\
\hline Paraguay & -501 & -556 & -559 & -385 & -767 & 421 & 324 & 193 & 68 & 70 & - & - & - & - & - \\
\hline \multicolumn{16}{|l|}{ Dominican } \\
\hline Republic & -879 & -1386 & -1405 & -1201 & -1586 & 425 & 346 & 475 & 292 & 290 & -21 & 49 & 183 & -9 & -4 \\
\hline Uruguay & -45 & -201 & -190 & -479 & -1224 & 510 & -162 & 111 & 295 & 125 & - & 96 & 150 & - & -93 \\
\hline Subtotal` $^{\wedge}$ & -8988 & -19040 & -22917 & -20776 & -25008 & 11813 & 7713 & 6577 & 8732 & 7796 & 211 & 238 & 2538 & 2147 & -36 \\
\hline Total & -32064 & -55282 & -56313 & -45012 & $-57 \quad 188$ & 24170 & 20511 & 13988 & 16000 & 9296 & 211 & 789 & 4705 & 2147 & 957 \\
\hline
\end{tabular}

${ }^{\mathrm{fe}}$ The warranted deficit is equal to the sum of the actual deficit and the total impact of the transitory external shocks on the balance of payments. It is also equal to warranted external financing (with minus sign).

${ }^{c}$ We define: actual net foreign financing is equal to the sum of the actual deficit on current account and the variation in total gross international reserves.

Preliminary figures.

'January-November.

'Excluding Brazil. 
Table 4

\title{
TYPOLOGY OF SHOCKS
}

\author{
Balance-of' \\ Adjustment \\ Financing \\ payments \\ Exogenous \\ domestic \\ shocks \\ External shocks \\ variables $^{a}$ \\ Export quantum \\ Depressed real \\ $\mathrm{a}<\mathrm{t}$ \\ effective exchange \\ rate \\ Permanent Transitory shocks \\ Endogenous \\ domestic \\ Average price of \\ exports \\ $a<\mathrm{t}$ \\ Import quantum \\ Depressed real \\ Recession in \\ Natural disasters \\ industrialized \\ countries \\ Recession in \\ industrialized \\ countries \\ Abnormally high \\ real international \\ interest rates \\ - Natural disasters \\ effective exchange \\ rate \\ Excess public \\ sector deficit \\ Average price of \\ imports excluding oil

$$
\text { a }>\mathrm{t}
$$ \\ Average price of oil

$$
\mathrm{a}>\mathrm{t}
$$ \\ Net factor service \\ payments $d$ \\ $\mathrm{a}>\mathrm{t}$ \\ - Excess net \\ external \\ indebtedness

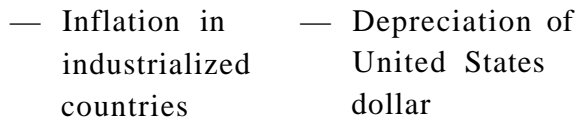 \\ - OPEC $\mathrm{I}^{\mathrm{e}} \quad-$ OPEC $2^{C}$ \\ - Excess net foreign \\ financing \\ - Abnormally high \\ real international \\ interest rates \\ - Reduction of \\ credit supply by \\ commercial banks \\ Long-term capita \\ $\mathrm{a}<\mathrm{t}$ \\ Short-term capital \\ account surplus \\ $\mathrm{a}<\mathrm{t}$ \\ - Depressed actual \\ real exchange rate \\ - Excessive public- \\ sector deficit \\ Source: Revised version of table 2 in Ground (1986). \\ "Deviation of actual values "a" from trend values " $t$ ". \\ Of goods and non-factor services. \\ "For an oil-exporting country the permanent income gain from OPEC 1 (i.e., the 1973/1974 oil price shack) would justify a \\ positive adjustment, that is, a structural increase of domestic absorption, while the windfall from OPEC 2 (i.e., the \\ $1979 / 1980$ oil price shock would call for an accumulation of international reserves. \\ Includes unrequited private transfers. \\ includes unrequited official transfers. \\ Includes the item "errors and omissions".
}


the shortage of foreign credit suffered by the non-oil-exporting Latin American economies in the years 1982 to 1985 amounted to $63 \%, 75 \%$, $64 \%$ and $84 \%$, respectively, of the amounts they would have needed to achieve efficient adjustment processes -on the assumption that their economies were free of rigidities and lags. In other words, the external credit they received and retained covered, in the years indicated, only $37 \%, 25 \%, 36 \%$ and $16 \%$, respectively, of the effects produced by transitory external shocks on their balances of payments (see table 3$)_{-}{ }^{9}$ According to our calculations, these Latin American countries were obliged to effect an enormous overadjustment, although in 1982, as in 1983, a large part of the scarcity of credit was due to substantial deficits on the short-term capital account (including "errors and omissions"). ${ }^{10}$ Since their economies do in fact contain imperfections, this shortage of external credit was bound to lead to production gaps and consequently to to the unnecessary welfare losses that the region has endured.

Although the oil-exporting countries maintained a surplus of foreign exchange during the early years of the 1980s the shortage of external finance suffered in 1985 by the Latin American economies as a whole reached an average of close on $70 \%$ of the amount they would have needed to cover their potential deficits on current account, that is, the deficits consistent with the maintenance of the economic growth rates that they achieved during the expansionary cycle of the postwar period (1950-1978), given the numerous shocks that their economies have endured in recent years (see table 4). ${ }^{11}$ All in all, considering the heavy falls in their import quanta caused by the dwindling of foreign lending and, in some cases,

\footnotetext{
${ }^{9}$ The calculation of the effects of shocks is based on a systematic comparison of the actual and trend values of the bala nce-of-payments variables and the construction of a typology of shocks (see table 4). The methodology is given in Ground (1986).

${ }^{10}$ The marked negative balances recorded in 1981, 1982 and 1983 in the short-term capital account reflected the results of Argentina, Mexico and Venezuela. In fact, in 1981 the negative balances in Argentina and Venezuela equalled $146 \%$ of that recorded in the region as a whole, and in 1982 and 1983 the deficits sustained in Argentina, Mexico and Venezuela totalled $137 \%$ and $89 \%$, respectively, of the regional deficits. (The cited statistics are from the ECLAC data bank.)
}

the pronounced rise in domestic demand for external assets (capital flight), the production losses suffered by the Latin American countries in recent years were, in fact, considerably lower than might have been expected, in the light of the close relation that existed between the growth in import quantum and the growth in gross domestic product in almost all the countries during the great postwar expansion (see table 5).

This result was of course decisively influenced by the application of domestic economic policies that fostered the production of tradeable goods and services. Thus, between 1980 and 1985 thirteen of the nineteen countries for which data are available increased their export quanta despite the decline (of 5\%) in the value of world exports. ${ }^{12}$

What is more, eight of them achieved it in a higher proportion than the expansion $(9 \%)$ of the quantum of world exports and six appreciably increased their share in the quantum of world exports. At the same time almost all the countries increased their production of importable goods and services.

\section{b) Transitory shocks or permanent shocks?}

Procyclical international credit policies - that is, those which result in excessive expansions of credit when countries are growing (as occurred in the 1970s) and inordinate contractions when they are in recession (as is happening now) - also are due to errors of judgment and differences of opinion regarding the nature of the causes of current account deficits of the developing countries.

In practice, the determination of the true nature of shocks is very problematic, since it involves judgments on the future course of

\footnotetext{
"The above-mentioned concept of scarcity of external finance, or what we may call the foreign exchange "gap", is calculated on the basis of the ratio between the actual current account and the potential current account deficit, where the latter is defined as the deficit that would be observed if the quantum of imports of goods and non-factor services equalled its trend value, given the actual values of the other balance-of-payments variables. For further details see note on table 2.

"The figures for world exports refer to goods only (IMF, several years).
} 
Table 5

\section{LATIN AMERICA: GROWTH RATE OF IMPORT QUANTUM AND OF GROSS DOMESTIC PRODUCT, 1950-1985}

\begin{tabular}{|c|c|c|c|c|c|c|}
\hline \multirow[b]{2}{*}{ Country } & \multicolumn{3}{|c|}{$\begin{array}{c}\text { Trend growth rates, } \\
1950-1978\end{array}$} & \multicolumn{3}{|c|}{$\begin{array}{c}\text { Actual accumulated } \\
\text { variations, 1980-1985 }\end{array}$} \\
\hline & $\underset{\text { quantum }}{\text { Import }} a$ & $\begin{array}{c}\text { Gross } \\
\text { domestic } \\
\text { product }\end{array}$ & $\mathrm{R}^{2}$ & $\begin{array}{l}\text { Import } \\
\text { quantum" }\end{array}$ & $\begin{array}{c}\text { Gross } \\
\text { domestic } \\
\text { product }\end{array}$ & $\begin{array}{l}\text { Export } \\
\text { quantum" }\end{array}$ \\
\hline Argentina & 2.00 & 3.56 & .655 & -60.2 & -12.0 & 49.5 \\
\hline Bolivia & 5.01 & 3.94 & .902 & -28.0 & -11.2 & -30.9 \\
\hline Brazil & 5.39 & 7.48 & .684 & -40.0 & 10.0 & 56.8 \\
\hline Colombia & 3.40 & 5.11 & .813 & 0.2 & 11.1 & 3.3 \\
\hline Costa Rica & 7.98 & 6.78 & .981 & -23.3 & 1.4 & 15.7 \\
\hline Chile & 4.45 & 3.34 & .831 & $-48.5^{b}$ & $-6.0^{\prime \prime}$ & $26.1^{\prime \prime}$ \\
\hline Ecuador & 3.74 & 6.00 & .959 & -26.3 & 13.0 & 33.7 \\
\hline El Salvador & 5.98 & 5.30 & .953 & 4.2 & -10.6 & -24.8 \\
\hline Guatemala & 5.43 & 5.25 & .912 & $-32.0^{*}$ & $-6.7^{\prime \prime}$ & $-9.8^{b}$ \\
\hline Haiti & 2.93 & 1.65 & .781 & 5.3 & -1.8 & 12.2 \\
\hline Honduras & 5.45 & 4.27 & .959 & -2.5 & 3.1 & 2.6 \\
\hline Mexico & 4.50 & 6.62 & .906 & -45.7 & 0.6 & 24.7 \\
\hline Nicaragua & 4.03 & 5.71 & .954 & -0.1 & 4.8 & -23.5 \\
\hline Panama & 7.17 & 6.51 & .987 & -14.0 & 12.3 & -3.4 \\
\hline Paraguay & 5.53 & 4.62 & .946 & -7.7 & 12.5 & 3.3 \\
\hline Peru & 5.45 & 4.78 & .914 & -31.2 & -2.9 & 4.6 \\
\hline Dominican Republic & 6.78 & 5.77 & .944 & -23.0 & 8.2 & 33.3 \\
\hline Uruguay & 0.89 & 1.40 & .129 & -50.2 & -16.8 & 6.5 \\
\hline Venezuela & 3.65 & 6.07 & .485 & -39.8 & -9.6 & -20.6 \\
\hline
\end{tabular}

Source; Prepared on the basis of data from ECLAC's data bank.

${ }^{a}$ Of goods and non-factor services.

${ }^{6}$ Actual accumulated variations 1981-1985.

events. In fact, it is impossible not to make mistakes when it is a question of predicting whether shocks are permanent or only transitory.

A good example of the negative results of mistaken predictions is provided by the case of the oil price shocks. Whereas the first jump in the relative price of crude has persisted for more than a decade and seems likely to remain in force for an indefinite period, the second has eroded completely. However, the international financial community initially judged that the first oil shock would be transitory and the second permanent and acted accordingly. ${ }^{13}$

\footnotetext{
${ }^{11}$ For example, in 1981 the World Bank (1981) adopted as its "...central price assumption... an annual increase of about $3 \%$ in real terms (in the price of oil) from 1980 to 1990, i.e., from US\$ 20.50 to US\$ 42 in constant 1980 dollars. Given this longterm perspective, the projections should remain unaffected by factors such as the softening of prices in mid-1981" (World Bank, 1981, 40). (Brackets added by author.) In the following year the institution maintained its prediction of a significant increase in the real long-term price of oil, although at a lower rate than that forecast in its previous report (although it extended it to 1995):
} 
Thus in 1974, under the aegis of the IMF, a special service was created for the granting of non-conditioned loans to help to cover the deficits caused by the first oil crisis. At the same time, by means of the so-called recycling process, the international commercial banks helped to finance the impact of the large increase in the relative price of hydrocarbons. In contrast, after the second oil crisis of 1979-1980, not only were no new facilities created to soften the impact of the new rise in the real price of oil on the balances of payments of the importing countries, but from 1982 onwards, the granting of credits was drastically reduced, just when the deficit countries found themselves affected by a new series of powerful external shocks. In short, from an efficiency point of view, the international financial community provided a generous amount of credit when circumstances did not warrant it and, after the retrenchment of the commercial banks, it did not lend a cent in circumstances which really called for it. ${ }^{14}$

It also may be noted that the dichotomy between permanent and transitory shocks usually is not interpretated with due precision. For example, if we adhere to the strict meaning of a permanent change in international market conditions, permanent shocks are unusual from

\footnotetext{
"After rising until mid-1981 the real price of oil fell for a period, as it did from 1975 to 1978; but this fall is not likely to affect the longterm upward price trend. This trend is determined by demand and supply conditions, which have not substantially changed over the past year. ...A real increase in the price of oil of some $2 \%$ annually from 1982 to 1995 seems most likely..., although it is impossible to be precise about the trajectory" (World Bank, 1982, 34).

${ }^{14}$ It should be remembered, however, that if efficiency considerations indicate that adjustment should take place, they also would call for it to be that phased in, according as the economy is affected by imperfections. From this standpoint, a temporary supply of external credit would have been justified after both oil crises. On the other hand, the trajectory of the international price of oil may not be independent of the willingness of the international financial community to accommodate or not systemwide, petroleum-related current account deficits. A decision to cover such deficits indefinitely might prolong petroleum price shocks, whereas a decision not to finance them might shorten their duration, inasmuch as the extent of the rise in the domestic relative price of oil at the country level varies inversely with the degree of accommodation of the system-wide balance-of-payments impact of petroleum price shocks. Once again, a phased in but progressive adjustment might constitute the most efficient response, irrespective of whether these shocks are regarded as transitory or permanent.
}

a historical standpoint; even secular relative price shocks are infrequent.

In this connection, mainstream economists used to argue that there are no secular relative price shocks, much less permanent ones. Witness all the abuse heaped on Raúl Prebisch when he maintained, in 1949, that Latin American countries' terms of trade had suffered a secular deterioration since the 1860s and argued that these countries should therefore actively promote structural adjustments in their economies in order to return to their potential growth paths (Haberler, I960; Prebisch, 1949).

In contrast, in the decade of the 1980s the developing economies are obliged to adjust to the impact of these shocks, frequently almost instantaneously. It is as though international shocks suddenly had become permanent phenomena. ${ }^{15}$

In the light of these considerations and in view of the costs inevitably involved in a brusque adjustment process in economies affected by rigidities and lags, it may be that in the interests of efficiency virtually all external shocks should

\footnotetext{
${ }^{\wedge}$ Consider, for example, the response made by Mr. de Larosière to a question about whether IMF conditionality was tightened in mid-1981: "If a country runs a balance-of-payments deficit amounting, let us say, to $8 \%$ of its gross domestic product $<\mathrm{GDP}$ ), and if in that particular case its sustainable deficit is considered to be in the order of $2 \%$ of its GDP, an adequate threeyear adjustment programme would imply an adjustment of some 2 percentage points a year in the deficit of that country. But suppose now, for the sake of the argument, that this same country has moved into a worse balance-of-payments position; for instance, a deficit of $12 \%$ instead of $8 \%$ of GDP because of an irreversible deterioration in its terms of trade and/ or because of a slippage in its domestic financial policies. Its long-term sustainable fina nee a ble position has not by the same token changed and it is still, in my example, at $2 \%$ of GDP. The necessary adjustment would imply a reduction of a little more than 3 percentage points a year in the course of the three-year programme. Now, $i n$ such a situation, which in fact often happens and has occurred in 1980 and 1981 with the worsening of international recession, the perception might have arisen that conditionality had tightened. But what has really happened is not a tightening of conditionality per se; it is a worsening of the external conditions of thecountry in question and the need for more adjustments" (de Larosière, 1982,4-5). Did the then Managing Director of the IMF mean to imply that the international recession would be a permanent phenomenon or that it was a result of the domestic policies of developing countries? Did the IMF base its policies on such premises? Moreover, in the last sentence of the quotation no reference is made to the need to distinguish between transitory and permanent shocks, rather, it is stated that countries should adjust when external conditions deteriorate.
} 
be regarded as transitory and, in consequence, their effects eligible for temporary financing.

Yet, transitory shocks are not uniform in character: they may be strictly cyclical, i.e., the counterpart of a past or future change in the opposite direction; or they may be asymmetrical, i.e., a change which, although transitory, is not and never will be the reflection of a movement in the opposite direction. ${ }^{16}$

Although the deficits caused by cyclical transitory shocks could be sustained without external borrowing - through the use of the international reserves accumulated during the favourable phase of the cycle - the financing of deficits caused by asymmetrical shocks implies the accumulation of external debt. It is possible to envisage cases in which transitory external shocks require a certain degree of adjustment in the interests of efficiency.

\section{c) The shortcoming of international condi- tio nality}

The belief that the International Monetary Fund's adjustment programmes impose unnecessary losses is widespread in developing countries. Although the recessionary bias of these programmes is basically due to the untoward shortage of foreign finance, the IMFs adjustment policies also involve unnecessary costs. ${ }^{17}$

\section{Domestic causes}

\section{a) Domestic versus external shocks}

The implementation of countercyclical policies, during the recessionary phase of the cycle implies the application of countercyclical policies during the expansionary phase as well. If the domestic policy stance is instead procyclkal during the growth phases as well as expansionary during the recessionary phases - a pattern that more or less describes the postwar experience of most of the Latin American

\footnotetext{
${ }^{16}$ The oil crisis of 1979/1980 might be an example of this last type of transitory shock.

"For an analysis of the deficiencies of IMF adjustment policies see Ground (1984). See also Williamson (1983) and Killick (1984).
}

countries until the advent of the present crisisthe external debt grows progressively, thus weakening in the long run the country's growth capacity and room for manoeuvre. Such a pattern eventually erodes the very rationale for countercyclical policies, international as well as domestic. However, phenomena such as the insufficient growth of the production of tradeable goods and services, excess external indebtedness, the retrenchment of commercial banks and capital flight are conditioned by shocks emanating from the international economy as well as by shocks stemming from untoward domestic economic policies.

Excess external indebtedness. One of the manifestations of the shocks deriving from domestic economic policies is the excessive expansion of the import quantum. ${ }^{18}$ During the 1970s and up to the early 1980s numerous Latin American countries immoderately expanded the domestic absorption of goods and services (real domestic expenditure). Although from 1982 onwards the reverse occurred as import quanta were slashed drastically the legacy of its inordinate previous growth remained, in the shape of an excess stock of external debt.

However, these spending sprees were due as much to supply side shocks as to domestic economic policy shocks. Money (i.e., nominal) domestic demand can evolve independently of supply, but the domestic absorption of goods and services is necessarily the result of the interaction of nominal domestic demand and supply, including of course both domestic production and net imports (foreign savings or finance).

The eagerness of the international commercial banks to fuel this prodigality - to finance current account deficits which, from the standpoint of efficiency, should not have been sustained - apparently reflected the banks' drive to adjust their portfolios after decades of little activity in the developing countries, as well as the international capital market imperfections that impelled bank lending to Latin America beyond the optimum or desired

\footnotetext{
${ }^{18}$ Here the words excessive and excess and their synonyms refer to the difference between actual and trend values of the variables in question.
} 
amount (Devlin, 1984a and 1984b; Sachs 1984). ${ }^{\text {iy }}$

In any event, "takes two to tango". The responsibility for the immoderate expansion of domestic spending or the untoward postponement of adjustment devolves as much on the international commercial banking community — which lent the money- as on the countries themselves —which borrowed it. From this observation issues the criterion of shared responsibility (or, as Prebisch said, "shared irresponsibility").

Although domestic policy shocks as well as permanent external shocks do call for adjustment, the burden inherited through not having adjusted to these shocks in the past -i.e., the (net) interest payments generated by the corresponding excess (net) external debt- is a joint responsibility. Consequently, half these interest payments should be financed by the international banks. ${ }^{20}$

As this has not occurred, the Latin American nations have found themselves faced with the dilemma of enduring an even more intensive adjustment or failing to completely fulfil their foreign commitments. In the event, the countries have chosen to make an effort disproportionate to their responsibility in the handling of the debt problem. Indeed, after sharing the financing of interest payments with external sources in 1982, the region as a whole financed $89 \%$ of its interest payments in 1983 , $78 \%$ in 1984 and $89 \%$ in 1985 (see table 1).

The reduction of foreign financing. A fall in the net inflow of long-term capital below trend, may well be a response to domestic policy shocks. Yet, as the pervasiveness of the curtailment of foreign finance in recent years suggests, factors beyond the purview of developing countries frequently exercise more influence than do their domestic policies on the

\footnotetext{
${ }^{19} \mathrm{~A}$ patent example of the procyclical bias of the international capital market was the overindebtedness of the oilexporting countries during this period.

${ }^{20}$ Note that excess net external indebtedness may reflect policy responses to the impact of transitory external shocks. For efficiency's sake one hundred per cent of the corresponding net interest payments should be financed (first with excess holdings of international reserves and when these are exhausted with foreign credit).
}

decisions of the international financial community to lend them money. Even if "a decline in the net inflow of capital below trend were to coincide with domestic policy shocks or a permanent deterioration in external conditions, the fact is that this decline necessarily involves a greater adjustment than that required by such shocks per se. Indeed, unless the country has access to additional foreign financing, shocks inevitably entail a proportionate reduction in the current account deficit. Hence, from the efficiency standpoint, whether a fall in the surplus on the long-term capital account below trend warrants compensatory foreign financing from sources such as the $\mathbb{M F}$ depends solely on whether the fall is considered transitory or permanent. $^{21}$

Capital flight. When external shocks are large domestic demand for foreign financial assets may surpass trend, in spite of the absence of domestic policy shocks. ${ }^{22}$ Nevertheless, when capital flight is unleashed domestic policies cannot be considered adequate however much the phenomenon may have been ignited by transitory external factors. Indeed, while developing countries cannot always obtain all the foreign finance they need, even if their domestic policies are adequate, they can certainly halt capital flight by applying appropriate exchange rate, fiscal and monetary policies.

The Latin American nations can hardly expect the international financial community to provide them with an adequate volume of credit

\footnotetext{
${ }^{21}$ However, if shocks emanate from domestic policies or the economy has been subject to permanent external shocks, the provision of foreign financing to compensate for a temporary decline in the net inflow of long-term capital below trend should be made to depend on the implementation of appropriate domestic policies.

${ }^{22}$ In fact, as Carlos Diaz-Alejandro (1984) observed: "Both capital flight and tax evasion by foreigners are openly encouraged by private and public actors in OECD countries. During 1984 there were reports that United States banks were engaged in highpowered campaigns to sell their certificates of deposit in several Latin American countries. The United States Treasury has announced plans to sell securities to foreign investors, who will not have to reveal their names; new regulations will also allow United States corporations to sell bearer bonds overseas without resorting to offshore subsidiaries, and security concerns hope to sell to overseas investors bearer bonds backed by United States Treasury bonds. Behaviour not permitted to domestic citizens is encouraged among foreigners ... Increasingly, the international system offers Latin American middle and upper classes comfortable possibilities for capital and personal exit..."
} 
if their own citizens are sending their savings out of the region. And even if the international commercial banks were willing to finance capital flight, the accumulation of external debt for this purpose, like the accumulation of external debt to compensate the balance-of-payments effects of any domestic policy shock, are expedients which in the long run are more costly than the alternative of adjustment. In consequence, when capital flight occurs adjustment, rather than foreign finance, should be resorted to.

\section{b) Domestic structural and institutional imperfections}

The inefficient adjustment of the Latin American economies also is rooted in domestic structural and institutional defects, which hamper the full employment of their productive factors, impart an inflationary bias to the price level and help to create a chronic dependence on external credit. In contrast to excess external indebtedness, these imperfections constitute a legacy attributable solely to flaws, in past domestic policies. Nonetheless, like excess external indebtedness, this is a phenomenon that can only be overcome in the medium and long term. Consequently, although the minimization of the cost of adjustment implies a phased process - since otherwise it will involve needless welfare losses - the rationale for the temporary financing of the impact of shocks also would call for the implementation of farreaching policy reforms designed to mitigate the domestic structural and institutional defects that help to create an overdependence on foreign financing to sustain economic growth during the expansionary phase of the cycle and to avoid gratuitous welfare losses during the trough of the cycle. 


\section{Proposals for reform}

\section{The strengthening and flexibilization of the lending capacity of the IMF}

In the last five years the international financial community has denied Latin America transitory financing of the balance-of-payments impact of shocks and therefore time for an efficient adjustment. From this incongruency issues, from a normative point of view, a large part of the needless welfare losses suffered by the Latin American peoples during recent years.

An ideal reform of the international capital market would reconcile the supply of resources available to the IMF, plus those it catalyzes from other sources, with the changing international demand for liquidity, and harmonize the amount of resources to which each country has access with each country's changing demand for foreign finance, on the basis of the efficiency criterion.

It is evident that this reform would involve an enormous increase in the IMF's lending capacity and therefore in the quotas of the institution's member countries. For instance, if we generalize from the 1982-1985 experience of the non-oil-exporting Latin American countries in respect of the effect on their balances of payments of the transitory external shocks and the capacity shown by the IMF to catalyze and mobilize resources from the rest of the international financial community for these countries (see table 3), we would be speaking of an increase of over $350 \%$ in IMF quotas. This would have an approximate gross cost of over US $\$ 8$ billion for the member countries of the Fund. ${ }^{23}$ In this connection, it may be recalled that our estimates of the unnecessary welfare losses suffered by Latin America in the 1982-1985 period ranged from US\$ 690 to 810 billion.

"This estimate was calculated from data on the gross cost that the latest rise $(45 \%)$ in the quotas of the IMF agreed in December 1983 would signify for the United States (Cline, 1983). It should be noted that if the rise in the quotas results in a higher level of world activity, its net cost is proportionately reduced.
It must be recognized, however, that to offset the imperfections of the international capital market it is not feasible to transform the efficiency criterion into a fixed international policy rule. Indeed, it is impossible to determine beforehand or even in the event the magnitude that the IMF's financing capacity should attain in order to avoid needlessly costly adjustments for the simple reason that it is impossible to predict which international shocks will be strictly cyclical, i.e., the counterpart of a movement in the opposite direction; which will be transitory but not cyclical, and which will be permanent.

In view of the extent of our ignorance and the costs that any brusque adjustment necessarily entails for the imperfect economies of the real world, our proposal is that all current account deficits attributable to external shocks should be financed for a certain period, irrespective of whether they are considered transitory or permanent. In other words, the (external) shocks themselves would determine the degree of potential access of each country to compensatory external finance, rather than the system of fixed quotas set without regard to the potential size of shocks which is currently used in the IMF.

Said period might be fixed on the basis of the average historical duration of cyclical troughs in the international economy; the ideal would be to take into account the optimum velocity of adjustment of each economy. Every deficit country would have the option of phasing in its adjustment in the course of this period, that is, of being assured, let us say during a four-year period, of compensatory foreign finance equivalent, for example, to $80 \%$ of the total impact of the external shocks in the first year, $60 \%$ in the second, $40 \%$ in the third and $20 \%$ in the last. A more gradual process would be justified in the case of economies that could show that they were not in a position to adjust themselves efficiently within the conventional period. 
The implementation of this reform would foster efficiency, at the country level by reducing the cost of adjustment and discouraging domestic policy shocks, since no external finance would be provided to compensate the impact of such shocks. At the same time it would tend to limit the accumulation of external debt to finance the impact of mutations in international market conditions and thereby would improve the performance of the developing economies in the long run. It likewise would allow the achievement of international levels of activity and trade higher than otherwise would be obtained; in particular, it would tend to diminish the intensity and shorten the duration of certain international shocks, such as the fall in commodity prices and interruptions in private capital flows to deficit countries.

Although it is equally impossible to calculate with any precision the lending capacity that the IMF would need to implement this reform, since the future magnitude of external shocks cannot be forecast with any certainty, it is possible to estimate in the event the influence they exercise on the balance of payments. The other element in our proposal for reform of current international adjustment policy is, then, the endowment of the IMF with a mechanism that will enable $i t$ to mobilize resources according to the changing magnitude of external shocks rather than to a rigid formula.

In this connection, the new adjustment programme agreed to between the Government of Mexico and the International Monetary Fund represents a very encouraging advance. Indeed, the programme proposed by the Mexican authorities to the IMF in their Letter of Intent of 22 July $1986^{24}$ is designed in function of an economic growth target, the magnitude of future shocks and the capacity of the economy to adjust, instead of in function of a fixed supply of foreign finance, as had been customary in traditional IMF adjustment programmes. Hence the financing needs, as well as the performance criteria and policy understandings, are made subject to the trajectory of the price of oil, to an estimate of the

"Published in lixcelsior on 28 July of that year. It was announced on 29 September that the adjustment programme and the amounts of financing had been ratified by the IMF and the 500 creditor banks of Mexico. economy's capacity to sustain cutbacks in absorption without production losses, and to the evolution of economic activity in relation to the target for its recovery. As a result of a more effective use of the considerable bargaining power Mexico possesses thanks to the enormous size of its external debt and the interdependence of the United States and Mexican economies, the country is slated to obtain credit in the amount of at least US\$ 12 billion between August 1986 and December 1987 compared with the US\$ 4 billion originally proposed by the international financial community. What is more, if the international price of oil should fall below nine dollars a barrel, provision is made for additional credit to finance fully its balance-of-payments effects up to a sum of US\$2.5 billion for three quarters. Subsequently, the economy would adjust gradually to the effects of any such decline in the price of hydrocarbons over the course of five quarters. Conversely, if the international price of oil were to exceed 14 dollars a barrel, the amount of external finance would be reduced in proportion to Mexico's increased income from petroleum exports. Furthermore, the supply of credit would be raised automatically by US $\$ 500$ million to cover a supplementary public investment programme should the economic growth target not be achieved in the first half of 1987. Finally, by virtue of the priority assigned to the recovery of economic activity, no attempt will be made to stabilize and adjust the economy simultaneously.

A precedent thus has been established by the international financial community for the use of a normative, efficiency-based approach to deal with adjustment. Nevertheless, the extension of this new international policy approach to adjustment in all the deficit countries will require a persistent campaign to institutionalize it through the introduction of reforms of the type indicated. Otherwise, after the spectre of a Mexican moratorium fades, the international financial community will go back to the traditional approach.

\section{The adaptation of domestic adjustment policies}

Without prejudice to the need for systemic reforms in the international capital market 
geared to minimize the avoidable costs of the adjustment process, the gratuitous welfare losses suffered by the deficit countries also could be reduced with appropriate reforms in domestic adjustment policies, both in those promoted by the international financial institutions and those implemented through the initiative of the countries themselves.

In this connection, significant and positive innovations have taken place in the content and mix of economic policies implemented in some recent adjustment programmes in which the IMF has participated. Thus in 1984 the Fund approved -apparently for the first time- a countercyclical fiscal policy for the second year of a Stand-by Arrangement with the Government of Chile (10 January 1983). Indeed, the target for the non-financial public sector deficit was raised from the figure of $2.3 \%$ of gross domestic product actually registered in 1983 to $4.5 \%$ of projected GDP in 1984, with a provision for a further increase equal to $0.8 \%$ of GDP if additional external finance equivalent to that amount were to materialize. In contrast, the IMF traditionally has insisted that the adjustment programmes it supports include major cutbacks in the non-financial public sector deficit in relation to gross domestic product. In September 1984, during the course of this same Stand-by Arrangement, the IMF also accepted -once again, apparently for the first time- a rise in tariffs from $20 \%$ to $35 \%$ of the CIF value of imports, despite the fact that the measure appeared to run contrary to one of the articles of the agreement.

Elsewhere, towards the middle of 1985 the IMF agreed to the introduction of generalized price controls in one of the adjustment programmes in which it was participating, namely the Stand-by Arrangement concluded with the Argentine Government (28 December 1984). The acceptance of this measure, which aimed at reconciling the population's inflationary expectations with the authorities' monetary targets in order to minimize the recessionary effect of the stabilization plan (Austral Plan), marked another policy precedent in IMF-supported adjustment programmes.

Finally, the adjustment programme agreed to between the Mexican Government and the IMF also contains innovations in the economic policy field. In effect, it combines a new approach to financial programming with structural and institutional reforms. Moreover, in contrast with traditional adjustment programmes, it does not seek to stabilize and adjust the economy simultaneously. In consequence, and thanks to the compensatory mechanisms agreed to as regards foreign financing, the targets for the criteria of execution will be provisional, depending on oilprice variations and the evolution of the gross domestic product, instead of fixed, as had been the norm. Moreover, a decidedly countercyclical exchange rate policy will continue to be applied. At the same time work will go forward on the structures of production and expenditure through far-reaching reforms of trade and taxation policy, the reduction and rationalization of the public sector and the active promotion of direct foreign investment. Finally, the target for the non-financial public sector deficit for 1987, representing $10 \%$ of projected gross domestic product, implies a reduction of no more than three percentage points from the estimated 1986 figure. This modest reduction is in line with the decision not to attempt to stabilize the price level while the economy is adjusting. For targeting purposes the effect of inflation on interest payments on the government's domestic debt will be excluded from the nonfinancial public sector deficit - another first for an IMF-supported adjustment programme.

Once again it is open to question whether these innovations constitute a new approach to adjustment policy, involve conjunctural deviations from the traditional paradigm, or whether they show that the IMF is in fact willing to adapt its policies to prevailing objective conditions, as it always has affirmed. On the other hand, they show that deficit countries are capable of putting over their points of view. At all events, there still may be room for improvement in the efficiency of the adjustment programmes sponsored by the IMF. ${ }^{25}$

\footnotetext{
${ }^{25}$ In another article the author presents a series of proposals for the palliation of the recessionary bias of IMF to nationality (Ground, 1987).
} 
There is, at the same time, ample room for rectifying the cyclical stance of the domestic policies of the Latin American countries. Indeed, this is imperative to the achievement of their growth potential. In many countries, however, this would not suffice to reduce within a reasonable period of time the gap between the actual and potential rates of economic growth, due precisely to the legacy of past incongruences in the economic policy, i.e., the excessive accumulation of external debt and domestic structural and institutional defects.

It must be emphasized, therefore, that the criterion of shared responsibility for excess external debt as well as the existing untoward scarcity of foreign credit fully justify Latin America's vindication that the international financial community should either provide more credit for interest payments on the external debt or reduce debt service payments. The region has considerable bargaining power since in the last three years (1983-1985) it has financed $85 \%$ of its interest payments on the external debt through domestic adjustments and production losses. This is a much higher proportion than it would have to assume if the costs of the excess build-up of external debt were distributed according to the principal of shared responsibility. On the other hand, the rationale for a true sharing of the costs of the excess external debt, as well as for temporary external financing of the impact of any external shock, implies at the same time reforms to mitigate domestic structural and institutional reforms. 


\section{Bibliography}

World Bank (1986): World development report 1986, Washington, D.C.

D.C. D.C.

(1984): World development report 1984, Washington,

1982). World development report, Washington, D.C

ECLAC (Economic Commission for Latin America and the Caribbean) (1985a): Preliminary balance of the Latin American economy 1985, Santiago, Chile.

(1985b): Economic Survey of Latin America and the Caribbean 1983, Santiago, Chile.

Cline, W. (1983): Debt and stability of the world economy. Policy analysis in international economics. Institute for International Economics, September.

Devlin, R. (1984a): Deuda, crisis y renegociación: el dilema latinoamericano. América Latina: deuda, crisis y perspectivas. Instituto de Cooperación Iberoamericana, et al. Madrid: Ediciones Cultura Hispánica, 67-101.

(1984b): Banca privada, deuda y capacidad negociadora de la periferia: teoría y práctica. El trimestre económico. No. 51 (3), July-September: 559-589.

Díaz-Alejandro, C. (1984): Latin American debt: I don't think we are in Kansas any more. Brookings papers on economic activity. No. 2: 335-389.

IMF (International Monetary Fund) (several years): International financial statistics. Washington, D.C.
(1982): A conversation with Mr. de Larosière. Finance and Development, Vol. 19, No. 2, June: 3-7.

Ground, R.L. (1987): EL sesgo recesivo de las políticas de ajuste del Fondo Monetario Internacional. El trimestre económico, No. 213, January-March: 43-74.

(1986): Perturbaciones, déficit, crisis y políticas de ajuste: un enfoque normativo. El trimestre económico, No. 212, October-December: 725-792.

(1984): Orthodox adjustment programmes in Latin America, CEPAL Review, No. 23, August: 45-82.

Haberler, G. (I960): Terms of trade and economic development. The economic development of Latin America. Howard S. Ellis (éd.). Mexico: Fondo de Cultura Económica, 325-350.

Killick, T. (éd.). (1984): The quest for economic stabilization: the iMF and the Third World. London: Heinemann Educational Books in association with the Overseas Development Institute.

Prebisch, R. (1950): The economic development of Latin America and its principal problems. New York: United Nations publication. Sales No.: 50.II.G.2.

Sachs, J. (1984): Comments. Brookings papers on economic activity. No. 2: 393-401.

Williamson, J. (1983): The lending policies of the International Monetary Fund. IMF conditionally. J. Williamson (éd.). Washington, D.C: Institute for International Economics, 605-660. 